Published July 2019

EKONOMIKAWAN : Jurnal Ilmu Ekonomi dan Studi Pembangunan

ISSN : 1693-7600 (Print), ISSN : 2598-0157 (Online), http://jurnal.umsu.ac.Id/index.php/ekawan

\title{
Determinan Pembangunan Daerah dan Angka HIV/AIDS di Indonesia
}

\author{
Nabilla Salma Khairunisa ${ }^{1^{*}}$, Estro Dariatno Sihaloho ${ }^{2}$ \\ ${ }^{1,2}$ Departemen Ilmu Ekonomi, Fakultas Ekonomi dan Bisnis Universitas Padjadjaran, \\ Jln. Dipati Ukur No. 35, Bandung, 40132, Jawa Barat, Indonesia \\ *e-mail : nabilla16003@mail.unpad.ac.id
}

\begin{abstract}
ABSTRAK
AIDS (Acquired Immuno Deficiency Syndrome) yang disebabkan oleh infeksi HIV (Human Immunodeficiency Virus) yang dapat menyebabkan hilangnya kekebalan tubuh sehingga penderita mudah terjangkit berbagai penyakit infeksi. Indonesia menjadi negara dengan posisi nomor tiga di dunia dalam tingginya jumlah penderita, dan Indonesia juga menjadi negara yang memiliki persebaran HIV/AIDS tercepat di dunia. Paper ini bertujuan untuk menganalisis bagaimana pembangunan suatu daerah baik melalui variabel independen seperti angka buta huruf, kepadatan penduduk, indeks pembangunan manusia, dan rasio gini akan mempengaruhi kasus HIV di Indonesia. Paper ini penting untuk dibaca agar tingkat HIV/AIDS di Indonesia mengalami penurunan. Epidemi HIV telah terbukti menjadi tantangan kesehatan bagi seluruh masyarakat global terbesar pada abad ke-21. Penulis menggunakan data sekunder pada tahun 2013 hingga 2015 dari Badan Pusat Statistik (BPS) dan Kementrian Kesehatan RI. Penulis membangun fixed effect model dan menggunakan Hausman Test serta analisis deskripsi. Hasil uji regresi menunjukkan bahwa angka buta huruf, kepadatan penduduk, indeks pembangunan manusia, dan rasio gini berpengaruh signifikan terhadap kasus HIV/AIDS di Indonesia.
\end{abstract}

Kata Kunci: HIV, Angka Buta Huruf, Kepadatan Penduduk, Dampak Ekonomi, Pembangunan Daerah. 


\title{
Determinants of Regional Development and Numbers of HIV/AIDS in Indonesia
}

\begin{abstract}
AIDS (Acquired Immuno Deficiency Syndrome) which caused by HIV (Human Immunodeficiency Virus) infection is diseases that causes loss of immunity and makes people are easily infected with infectious diseases. Currently, Indonesia stands at third place in the world for the number of sufferers / victims, and also a country with the fastest spread of HIV / AIDS in the world. This paper aims to analyze how the development of a region either through independent variables such as the illiteracy rate, population density, Human Development Index (HDI), and gini ratio will affect HIV cases in Indonesia. This paper is really important to be read in order to reduce the rate of HIV / AIDS in Indonesia. The HIV epidemic has proven to be the biggest global public health challenge of the 21st century. The author uses secondary data in 2013 to 2015 from the Central Bureau of Statistics (BPS) and Ministry of Health in Indonesia. The author builds a fixed effect model and used Hausman Test and decryption analysis. The result of the regression test shows that the illiteracy rate, population density, Human Development Index (HDI), and gini ratio have significant effect on HIV / AIDS cases in Indonesia.
\end{abstract}

Keywords : HIV, The Illiteracy Rate, Population Density, Economy Impact, Regional Development.

\section{PENDAHULUAN}

"Menurut laporan WHO pada akhir tahun 2009, sekitar 33,3 juta orang hidup dengan HIV di tubuhnya dan sekitar 2,6 juta orang dengan kasus infeksi baru HIV, dan 1,8 juta orang meninggal yang diakibatkan oleh AIDS, termasuk 260.000 diantaranya merupakan anak-anak. Selain itu, sekitar 2000 anak di bawah 15 tahun tertular virus HIV, bahkan virus ini telah menewaskan 1400 anak di bawah usia 15 tahun, serta menginfeksi lebih dari 6000 orang usia produktif" (Purwaningsih \& Widayatun, 2008).

Jumlah kasus HIV/AIDS yang ada di Indonesia jumlahnya semakin meningkat. Data laporan hasil Riset Kesehatan Dasar menunjukkan total kasus HIV di Indonesia sebesar 30.935, dengan persentase HIV tertinggi pada kelompok umur 25 hingga 49 tahun yaitu sebesar 69,7\%, diikuti oleh kelompok umur 20 hingga 24 tahun sebesar 16,6\%, serta pada kelompok diatas 50 tahun sebesar 7,2\% (Data Kementrian Kesehatan RI, 2015). Rasio HIV antara laki-laki dan perempuan adalah sebesar 2:1 atau dua laki-laki dibandingkan satu perempuan. 
Published July 2019

EKONOMIKAWAN : Jurnal Ilmu Ekonomi dan Studi Pembangunan

ISSN : 1693-7600 (Print), ISSN : 2598-0157 (Online), http://jurnal.umsu.ac.Id/index.php/ekawan

Sementara persentase faktor risiko HIV tertinggi terjadi akibat hubungan seks berisiko pada heteroseksual yaitu sebesar 47\%, diikuti dengan LSL atau lelaki seks lelaki sebesar $25 \%$, akibat penggunaan jarum suntik tidak steril pada kelompok pengguna narkoba yang memakai jarum suntik sebesar 3\%, serta faktor-faktor lainnya sebesar $25 \%$.

Sedangkan untuk persentase jumlah AIDS tertinggi yaitu pada kelompok umur 30 hingga 39 tahun sebesar 37,7\%, diikuti kelompok umur 20 hingga 29 tahun sebesar 29,9\%, serta kelompok umur 40 hingga 49 tahun sebesar 19\%. Untuk rasio antara laki-laki dan perempuan sebesar 2:1 atau dua laki-laki dibandingkan satu perempuan yang menderita AIDS di Indonesia. Sementara persentase faktor yang menyebabkan risiko AIDS tertinggi terjadi pada hubungan seks risiko pada heteroseksual yaitu sebesar 73,48\%, dilanjutkan oleh LSL atau lelaki seks lelaki sebesar $10,5 \%$, serta akibat penggunaan jarum suntik yang tidak steril pada kelompok pengguna narkoba yang memakai jarum suntik sebesar 5,2\%, dan perinatal sebesar 2,6\%.

Jumlah infeksi HIV tertinggi terjadi di provinsi DKI Jakarta yaitu sebesar 40000, diikuti oleh Jawa Timur sebesar 26052, Papua sebesar 21474, Jawa Barat sebesar 18727, dan Jawa Tengah sebesar 13547. Sedangkan AIDS terbanyak terjadi di Jawa Timur sebesar 14499, Papua sebesar 13335, DKI Jakarta sebesar 8105, Bali sebesar 5934, Jawa Tengah sebesar 5049, Jawa Barat sebesar 4919, Sumatera Utara sebesar 3761, Kalimantan Barat sebesar 2481, Sulawesi Selatan sebesar 2321, dan NTT sebesar 1935.

AIDS menyebabkan kematian sebesar lebih dari 25 juta orang sejak adanya AIDS di dunia pada tahun 1981 (Kemenkes RI, 2002). Jika di Indonesia, sejak kasus HIV/AIDS pertama kali muncul yaitu pada tahun 1987 di Bali, jumlah kasus HIV/AIDS semakin menyebar dan bertambah pada seluruh daerah di Indonesia. Diperkirakan, HIV/AIDS telah menginfeksi antara 172.000 hingga 219.000 orang yang ada di Indonesia (Departemen Kesehatan, 2006).

Penderita AIDS dinyatakan sebagai penular dan pembawa virus HIV. Salah satu cara menurunkan kasus HIV yaitu dengan mengubah perilaku seks di masyarakat. Hal itu disebabkan karena AIDS merupakan penyakit yang mematikan, biasanya dalam kurun waktu kurang lebih lima tahun setelah penderita dinyatakan menderita AIDS, apabila tidak ditangani maka rata-rata akan meninggal dunia.

Data yang digunakan secara resmi untuk mengetahui jumlah kasus HIV/AIDS yang ada di Indonesia saat ini dikeluarkan oleh Ditjen PPM dan PL DEPKES RI yang terbit secara periodik yaitu setiap tiga bulan. Namun data tersebut hingga saat ini belum dilengkapi dengan karakteristik sosial ekonomi penderita, seperti ekonomi, pendidikan, status migrasi, dan jenis pekerjaan. Padahal ketersediaan data tersebut penting untuk mengkaji kasus-kasus HIV/AIDS yang ada di Indonesia yang dapat membantu upaya dan strategi penanganan HIV/AIDS.

Menurut penelitian di Moscow, risiko tertinggi untuk terinfeksi HIV/AIDS yaitu kelompok perempuan pekerja seks yaitu sebesar 79\%. Selain itu, menurut survei di tahun 1998, sebanyak 54\% perempuan pekerja seks memilih pekerjaannya didasari karena alasan kebutuhan ekonomi dan kesulitan mendapatkan pekerjaan karena rendahnya pendidikan yang dimiliki. 
Published July 2019

EKONOMIKAWAN : Jurnal Ilmu Ekonomi dan Studi Pembangunan

ISSN : 1693-7600 (Print), ISSN : 2598-0157 (Online), http://jurnal.umsu.ac.ld/index.php/ekawan

Indonesia merupakan salah satu negara berkembang di dunia dengan jumlah penduduk yang berada di bawah garis kemiskinan sebanyak 39,05 juta orang atau 17,75\% dari jumlah total penduduk (Badan Pusat Statistik, 2007). Kemiskinan dan HIV/AIDS adalah dua hal yang berhubungan erat, karena kemiskinan merupakan faktor yang menyebabkan seseorang dekat dengan perilaku-perilaku yang memiliki risiko terkena HIV/AIDS. Salah satu perilaku akibat kemiskinan yaitu wanita yang mencari tambahan pemasukan keuangan dengan menjadi PSK karena jumlah lapangan pekerjaan dan pencari kerja tidak seimbang mengakibatkan sulitnya mendapatkan pekerjaan. Menurut Departemen Kesehatan RI pada tahun 2006, jumlah PSK pada tahun 2006 adalah antara 177000 hingga 265000 orang dengan jumlah pengguna seks komersial 7000 hingga 10000 orang (Rokhmah, 2015).

Selain itu, menurut Menteri Kesehatan tahun 2012 hingga 2016, pola penularan HIV/AIDS tertinggi melalui transmisi seksual sebesar $81,8 \%$. Strategisnya letak geografis Indonesia sehingga sangat baik untuk sektor perdagangan dan pariwisata menjadisalah satu faktor mempercepat peningkatan kasus HIV/AIDS.Meningkatnya pekerja atau wisatawan asing yang masuk ke Indonesia mengakibatkan penduduk lokal menjadi rentan terkena infeksi HIV/AIDS. Selain itu, menurut data dari Kanwil Departemen Kesehatan Jawa Timur menunjukkan terus terjadinya peningkatan kasus HIV/AIDS di antara para tenaga kerja Indonesia yang bekerja di luar negeri dari tahun ke tahun (Purwaningsih \& Widayatun, 2008).

Selain itu, adanya perpindahan penduduk dalam jangka pendek seperti turis dan pelaut merupakan faktor penting yang dapat meningkatkan kasus HIV/AIDS di Indonesia. Pergerakan penduduk yang sirkuler ini, menyebabkan tingginya kemungkinan bagi seseorang untuk berhubungan seks dengan pasangan sementara di tempat lain. Hal ini banyak terjadi di daerah Bali, banyaknya wisatawan asing yang berkunjung ke Bali menjadi faktor yang mempercepat arus penularan HIV/AIDS. Ditemukannya kasus HIV/AIDS pertama di Indonesia pada warga negara BeIanda yang berkunjung di Bali pada tahun 1987 menjadi bukti yang kuat bahwa penularan HIV/AIDS yang ada di Indonesia sangat berkaitan dengan mobilitas penduduk.

Pendidikan yang rendah serta pengetahuan yang kurang tentang penyebaran HIV berhubungan erat dengan peningkatan penyebaran virus HIV. Menurut survei, PSK memiliki pendidikan yang mayoritas rendah, sebagai contoh PSK di Lokalisasi Teluk Bayur, Bangka Belitung yang berpendidikan SD dan SMP sebesar 34,2\%. Karena pendidikan yang rendah, mereka sulit mendapat pekerjaan sehingga memilih menjadi PSK untuk memenuhi kebutuhannya.

Selain itu, di Papua memiliki risiko penyebaran HIV yang tinggi akibat kurangnya pendidikan dan pengetahuan mengenai seks sehingga mengakibatkan melakukan hubungan seksual yang tidak aman. Hanya $17,9 \%$ penduduk Papua yang menggunakan kondom selama melakukan hubungan seksual dengan alasan tidak nyaman saat menggunakannya. Padahal dengan tidak menggunakan kondom pada saat melakukan hubungan seksual, inilah yang menjadi salah satu faktor utama penyebaran virus HIV. 
Published July 2019

EKONOMIKAWAN : Jurnal Ilmu Ekonomi dan Studi Pembangunan

ISSN : 1693-7600 (Print), ISSN : 2598-0157 (Online), http://jurnal.umsu.ac.Id/index.php/ekawan

Oleh karena itu, terdapat korelasi yang erat antara pembangunan dan kesehatan pada suatu daerah. Dengan pembangunan daerah yang baik, maka sosial ekonomi daerah pun meningkat pula baik pada sektor ekonomi, pendidikan, serta kesejahteraan masyarakatnya. Didukung dengan komitmen global untuk meningkatkan status kesehatan yang tercantum dalam Tujuan Pembangunan Milenium (Millennium Development Goals-MDGs). Tujuan tersebut antara lain: (1) menurunkan angka kematian anak sebesar dua pertiga pada tahun 2015 dari tahun 1990; (2) menurunkan angka kematian ibu yang melahirkan sebesar tiga perempatnya pada tahun 2015 dari tahun 1990; dan (3) menahan peningkatan prevalensi dan penyebaran HIV/AIDS serta penyakit utama lainnya pada tahun 2015. Tujuan pembangunan millennium tersebut akan fokus terhadap pengurangan kemiskinan yang ada dengan beberapa tujuan kesehatan, sehingga tercapai hubungan antara upaya penurunan kemiskinan dengan investasi yang ada di bidang kesehatan terutama penyakit HIV/AIDS.

Beberapa sejarah telah membuktikan bahwa cepatnya pertumbuhan ekonomi yang didukung oleh inovasi dan investasi di bidang kesehatan, dapat memberantasberbagai penyakit dan terjadinya peningkatan gizi, termasuk memberantas penyakit HIV/AIDS. Hal ini telah terjadi di beberapa negara, seperti Inggris, Jepang dan Amerika Selatan pada awal abad ke-20, serta pembangunan negara-negara di Eropa Selatan dan Asia Timur sejak tahun 1950 hingga 1960.

Maka dari itu, penulis mengangkat judul Determinan Pembangunan Daerah dan Angka HIV/AIDS di Indonesia agar pembaca dapat mengetahui variabel apa saja yang mempengaruhi tingkat HIV/AIDS di negara berkembang terutama di Indonesia. Penulis berharap dengan mengetahui variabel apa saja yang dapat mempengaruhi tingkat HIV/AIDS, maka dapat mengurangi kasus HIV/AIDS khususnya di Indonesia.

\section{KAJIAN TEORI}

\section{Pengertian HIV/AIDS}

"HIV atau Human Immunodeficiency Virus adalah retrovirus yang menyerang sel-sel pada sistem kekebalan tubuh manusia, sehingga mengakibatkan tubuh kehilangan kekebalan dan imunitas terhadap serangan yang masuk menjadikan tubuh lemah dan rentan terkena infeksi" HIV menyebabkan menurunnya imunitas tubuh manusia secara perlahanlahan, dengan masa inkubasi selama 5 hingga 15 tahun untuk muncul sepenuhnya. HIV inilah yang menjadi agen pembawa penyakit AIDS.

AIDS atau Acquired Immune Deficiency Syndrome adalah penyakit yang timbul akibat menurunnya imunitas tubuh manusia yang ditandai dengan timbulnya serangkaian infeksi yang menyebabkan berbagai penyakit, sehingga daya tahan tubuh menjadi menurun drastis. Faktor utama penyebab penyakit AIDS adalah infeksi virus HIV" (World Health Organization, 2005). HIV dapat ditularkan melalui kontak seksual, pemakaian jarum bekas, dan transfusi darah dengan darah yang terinfeksi. Selain itu, wanita yang terinfeksi HIV juga dapat menularkan HIV ke bayi mereka pada sebelum atau semasa kelahiran (CDC, 2007). 
Published July 2019

EKONOMIKAWAN : Jurnal Ilmu Ekonomi dan Studi Pembangunan

ISSN : 1693-7600 (Print), ISSN : 2598-0157 (Online), http://jurnal.umsu.ac.ld/index.php/ekawan

\section{Cara Pengobatan HIV/AIDS}

Pengobatan dan vaksinasi HIV/AIDS hingga saat ini masih belum ditemukan solusinya, satu-satunya solusi yang ditemukan oleh WHO yaitu melalui obat-obatan ARV (Anti Retro Viral). Dengan mengonsumsi obat-obatan ARV, maka dapat menurunkan jumlah virus HIV di dalam tubuh penderita hingga mencapai batas normal, sehingga penderita dapat beraktivitas sehari-hari seperti biasa. Pengobatan ini tidak dapat memusnahkan virus HIV di dalam tubuh penderita, namun ARV hanya dapat menekan jumlah virus HIV sehingga menahan timbulnya AIDS. Oleh karena itu, obat-obatan ARV wajib dikonsumsi penderita HIV/AIDS selama hidupnya untuk bertahan hidup.

\section{HIV/AIDS dan Dampak Ekonomi}

HIV/AIDS akan menyebabkan timbulnya pengeluaran yang tinggi, bagi para penderita dan juga pemerintah. Ini disebabkan karena belum adanya obat yang menyembuhkan secara total HIV/AIDS, sehingga penderita dan keluarganya harus menanggung besarnya biaya perawatan untuk memperpanjang usia penderita HIV/AIDS. Besarnya biaya yang dikeluarkan untuk membayar pengobatan dan perawatan akan semakin besar, sementara penghasilan dari penderita biasanya tetap bahkan berkurang akibat menderita penyakit HIV/AIDS.

"Dampak HIV/AIDS terhadap perekonomian suatu negara adalah memperlambat terjadinya pertumbuhan ekonomi karena HIV/AIDS merusak penduduk yang memiliki usia produktif. Hal itu disebabkan karena penderita HIV/AIDS yang sudah parah, sudah tidak bisa bekerja, dan membutuhkan sekali fasilitas kesehatan yang baik. Selain itu, daerah yang memiliki jumlah penderita HIV/AIDS yang besar dapat meninggalkan banyak anak yatim piatu yang menjadi beban negara"(Piot, Greener, \& Russell, 2007).

Tingkat kematian yang semakin besar juga dapat melemahkan human capital di suatu negara. HIV/AIDS juga dapat menurunkan pemasukan pajak negara dan menghabiskan dana publik sebagai biaya pengobatan penderita HIV/AIDS yang disubsidi oleh pemerintah. Padahal dana ini bisa dialokasikan untuk kebutuhan yang lain. Keadaan seperti ini akan menambah beban dari keuangan negara sehingga dapat berdampak melambatnya pertumbuhan ekonomi suatu negara.

"Dawn C. Parker di tahun 2009 meneliti mengenai eksplorasi hubungan antara jumlah HIV/AIDS dengan ketersediaan tenaga kerja, jumlah konsumsi makanan, sumber daya rumah tangga, produktivitas sektor pertanian, dan status kesehatan di daerah bagian tenggara pedesaan Uganda. Hasil penelitian tersebut menjelaskan bahwa penyakit HIV/AIDS berdampak negatif atau buruk terhadap keadaan ekonomi, lingkungan, dan sosial di seluruh SubSahara Afrika" (Parker, Jacobsen, \& Komwa, 2009). Hal itu disebabkan karena HIV/AIDS menyebabkan meningkatnya jumlah anak yatim piatu dan janda, jumlah tenaga kerja berkurang dan hilangnya kepemilikan aset tanah. Selain itu, HIV/AIDS juga mempengaruhi jaring-jaring masyarakat tertentu yang saling terhubung dengan cara merusak keluarga dan memberikan kombinasi dampak yaitu stigma negatif dan beban ekonomi. Epidermik HIV/AIDS mempunyai kapasitas yang besar untuk memperbesar semua masalah sosial bagi penderita. Ketika HIV/AIDS menyerang, mereka yang sudah miskin maka dampaknya lebih hebat lagi. Akibatnya,HIV/AIDS memperdalam dan memperparah kemiskinan yang sudah ada. 


\section{Published July 2019}

\section{EKONOMIKAWAN : Jurnal Ilmu Ekonomi dan Studi Pembangunan}

ISSN : $1693-7600$ (Print), ISSN : 2598-0157 (Online), http://jurnal.umsu.ac.ld/index.php/ekawan

\section{HIV/AIDS di Indonesia}

Indonesia memiliki kasus HIV/AIDS yang semakin hari dilaporkan semakin bertambah. Sebagai contoh, di Kabupaten Malang dilaporkan bahwa jumlah pengidap HIV/AIDS selama tiga tahun terakhir meningkat tajam. Sejak tahun 2005 hingga tahun 2006 meningkat 200\%, dari 27 menjadi 97 orang. Di daerah lain, yaitu di provinsi Papua terdapat suatu daerah yang sebagian besar kantong darah yang siap ditransfusikan ternyata tercemar oleh virus HIV. Dengan demikian, pasien yang seharusnya perlu mendapatkan tambahan darah, misalnya jika terserang Demam Berdarah Dengue (DBD), maka pasien tersebut terpaksa melakukan pilihan yang sangat sulit yang sama-sama membahayakan kesehatan dirinya yaitu tidak mendapatkan tambahan darah ataupun mendapatkan tambahan darah yang tercemar virus HIV yang pada akhirnya juga membahayakan hidupnya (human survival).

\section{METODE}

Metode yang gunakan dalam penelitian ini menggunakan regresi data panel tahun 2013 hingga 2015. Data yang digunakan diambil dari data sekunder yang bersumber dari Badan Pusat Statistik (BPS) dan Kementrian Kesehatan atau dapat diakses melalui bps.go.id, kemenkes.go.id, dan depkes.go.id. Data-data yang diambil diolah menggunakan Software STATA14. Penulis juga menggunakan fixed effect model dan metode analisis deskripsi untuk menjelaskan hubungan antara faktor-faktor yang dapat mempengaruhi kasus HIV/AIDS yang ada di Indonesia.

Objek dalam penelitian ini adalah jumlah kasus HIV/AIDS, persentase buta huruf, jumlah kepadatan penduduk (jiwa/ $\mathrm{km}^{2}$ ), indeks pembangunan manusia, dan rasio gini. Data diambil dari jumlah seluruh provinsi di Indonesia pada tahun 2013 hingga 2015, yaitu sebanyak 34 provinsi.

Penulis juga melakukan uji asumsi agar hasil yang diperoleh mampu untuk memenuhi syarat BLUE atau Best, Linear, Unbiased, Estimator. Model yang dihasilkan sebagai berikut :

Keterangan :

$$
\mathrm{y}_{\mathrm{it}}=\hat{\beta}_{0}+\hat{\beta}_{1} \mathrm{X}_{\mathrm{it}}+\hat{\beta}_{2} \mathrm{X}_{\mathrm{it}}+\hat{\beta}_{3} \mathrm{X}_{\mathrm{it}}+\hat{\beta}_{4} \mathrm{X}_{\mathrm{it}}+\mathrm{u}_{\mathrm{it}}
$$

$\mathrm{y}_{\text {it }} \quad=$ Jumlah Kasus HIV/AIDS

$\hat{\beta}_{0} \quad=$ Konstanta

$\hat{\beta}_{1} X_{\text {it }}=$ Jumlah penduduk yang buta huruf

$\hat{\beta}_{2} \mathrm{X}_{\mathrm{it}}=$ Jumlah kepadatan penduduk

$\beta_{3} X_{i t}=$ Indeks pembangunan manusia

$\hat{\beta}_{4} X_{\text {it }}=$ Rasio gini

$\mathrm{u}_{\mathrm{it}} \quad=$ Error

Tujuan model ini untuk menginterpretasikan pengaruh antara persentase angka buta huruf, jumlah kepadatan penduduk (jiwa/ $\mathrm{km}^{2}$ ), indeks pembangunan manusia, dan rasio gini terhadap kasus HIV/AIDS yang ada di Indonesia. 
Published July 2019

EKONOMIKAWAN : Jurnal Ilmu Ekonomi dan Studi Pembangunan

ISSN : 1693-7600 (Print), ISSN : 2598-0157 (Online), http://jurnal.umsu.ac.Id/index.php/ekawan

\section{HASIL DAN PEMBAHASAN}

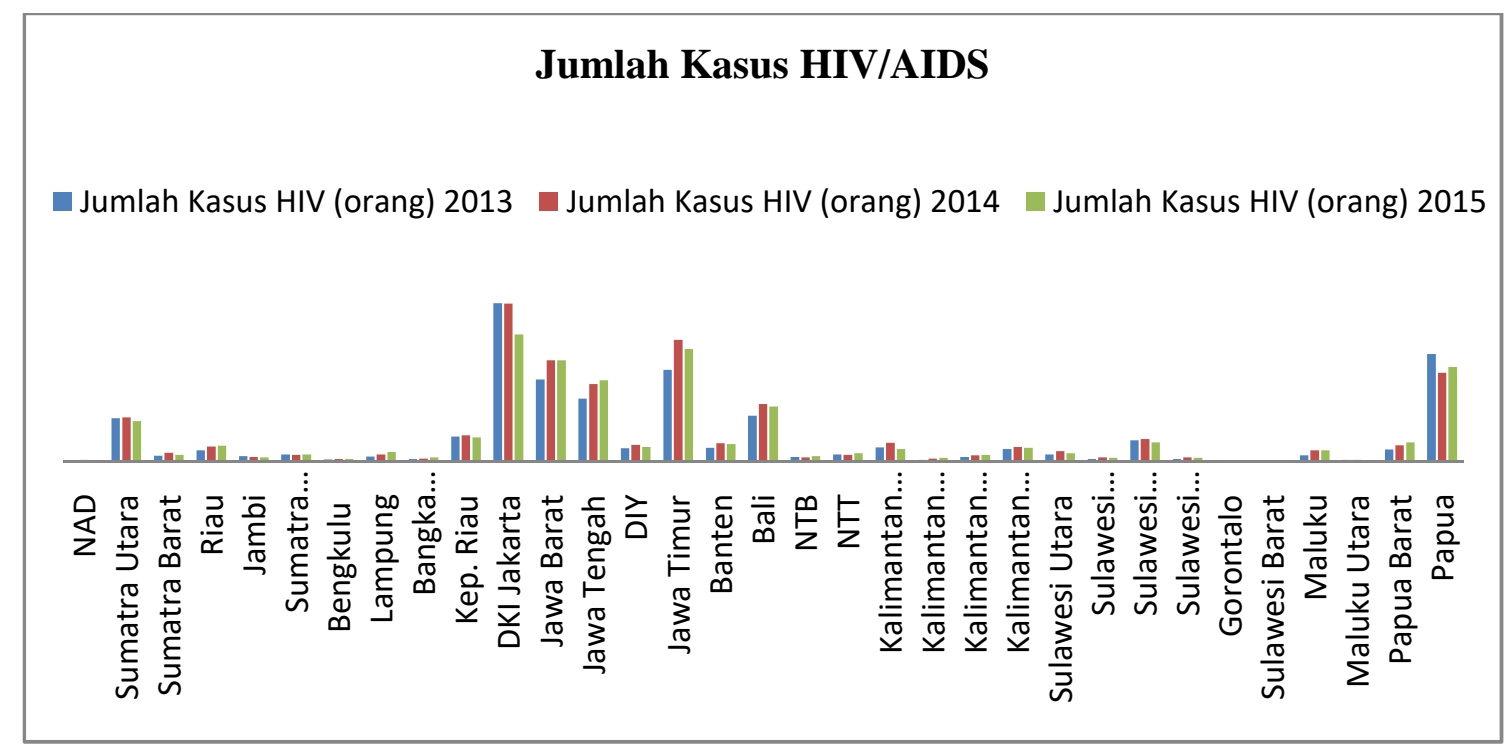

Sumber : Riskesdas 2015

Gambar 1. Jumlah Kasus HIV/AIDS 2013-2015 di Indonesia

Berdasarkan gambar 1, memperlihatkan bahwa jumlah kasus HIV/AIDS yang ada di Indonesia. Provinsi tertinggi yang terdapat kasus HIV/AIDS adalah propinsi DKI Jakarta dan disusul oleh provinsi Jawa Timur, Jawa Barat, Papua, Jawa Tengah, dan Bali. Sedangkan Sulawesi Barat, Gorontalo, NAD, dan Maluku Utara adalah provinsi dengan jumlah kasus HIV/AIDS terendah pada tahun 2013 hingga 2015.

Setelah dilakukan regresi, penulis melihat angka buta huruf mempengaruhi kasus HIV/AIDS di Indonesia. Nilai p-value sebesar 0.009 dan kurang dari 0,01, sehingga signifikan hingga level 1\%. Hal ini menunjukkan peningkatan angka buta huruf sebanyak 1\%, maka akan terjadi peningkatan jumlah kasus HIV/AIDS di Indonesia sebanyak 1 orang.

"Melek aksara adalah kemampuan untuk mengidentifikasi, mengerti, menerjemahkan, membuat, mengkomunikasikan, dan mengolah isi dari rangkaian tulisan yang terdapat pada bahan-bahan cetak dan tulisan yang berkaitan dengan berbagai situasi" (Unesco, 2017). Angka buta huruf di Indonesia kini sebesar 2,07\%.

Gambar 2 menunjukkan bahwa angka buta huruf di Indonesia tertinggi pada tahun 2013 adalah Papua sebesar 31,44\%. Hal ini beriringan dengan jumlah kasus HIV/AIDS di Indonesia yang menjadikan provinsi Papua menjadi provinsi pada tingkat keempat teratas yang terdapat kasus HIV/AIDS di Indonesia.

Angka melek huruf juga dapat digunakan menjadi indikator dalam melihat perkembangan baik atau buruknya pendidikan penduduk di suatu daerah. Semakin tingginya angka buta huruf di suatu daerah, maka menyebabkan mutu dan kualitas sumber daya manusia semakin rendah. 
Published July 2019

EKONOMIKAWAN : Jurnal Ilmu Ekonomi dan Studi Pembangunan

ISSN : 1693-7600 (Print), ISSN : 2598-0157 (Online), http://jurnal.umsu.ac.ld/index.php/ekawan

Penduduk yang bisa membaca dan menulis diasumsikan memiliki kemampuan menyerap informasi, baik dalam bentuk lisan maupun tulisan (BPS, 2017). Semakin rendahnya pendidikan seseorang, maka mengakibatkan kurangnya kesadaran baik sebagai orang tua, keluarga, atau masyarakat akan kepedulian terhadap bahaya penularan dan dampak dari HIV/AIDS. Hal tersebut menyebabkan sebagai salah satu pemicu terus meningkatnya jumlah kasus HIV/AIDS di Indonesia, terutama di daerah yang pendidikannya tertinggal.

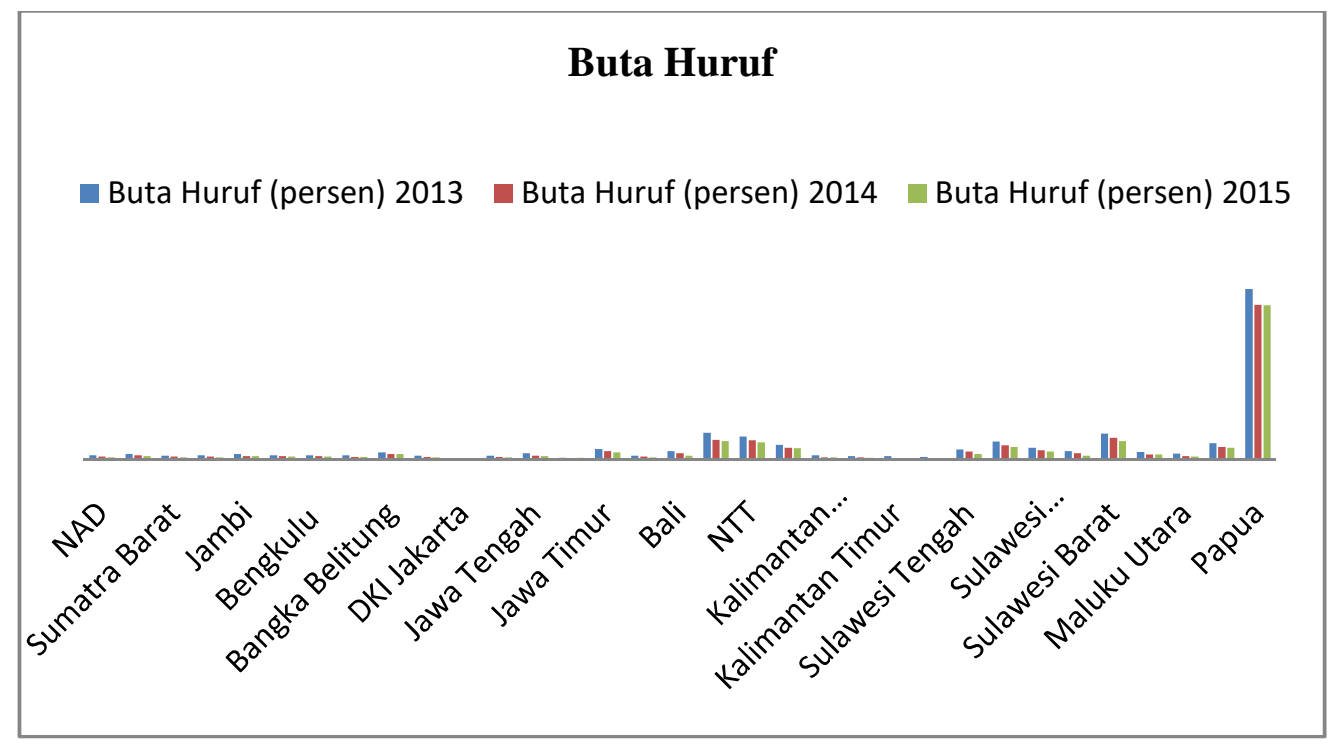

Sumber : BPS

Gambar 2. Tingkat Buta Huruf 2013-2015 di Indonesia

Penulis juga melihat variabel independen lainnya yang mempengaruhi kasus HIV/AIDS yaitu tingkat kepadatan penduduk yang dihitung dengan membagi antara jumlah penduduk dengan luas area yang mereka tempati. Tingkat kepadatan penduduk dapat mempengaruhi kasus HIV/AIDS di Indonesia, dimana nilai p-value sebesar 0,000 dan kurang dari 0,01 sehingga signifikan pada level $1 \%$.

HIV/AIDS tidak dapat ditularkan melalui hubungan sosial yang wajar, seperti berjabatan tangan, penggunaan peralatan makan dan minum yang sama, melalui gigitan nyamuk, bersentuhan, berpelukan, melalui air kolam renang, dan penggunaan kamar mandi atau WC. Mayoritas HIV/AIDS ditularkan melalui hubungan seks dan penggunaan jarum suntik. Lebih dari $80 \%$ jumlah penderita HIV/AIDS diderita oleh kelompok usia yang produktif terutama dialami oleh laki-laki, namun proporsi penderita HIV/AIDS yang dialami oleh perempuan cenderung terus meningkat. 
Published July 2019

EKONOMIKAWAN : Jurnal Ilmu Ekonomi dan Studi Pembangunan

ISSN : 1693-7600 (Print), ISSN : 2598-0157 (Online), http://jurnal.umsu.ac.Id/index.php/ekawan

Daerah dengan kepadatan penduduk yang rendah menyebabkan tingginya HIV/AIDS, hal tersebut terjadi di provinsi Papua. Pada grafik 3 diperlihatkan Papua menempati provinsi dengan persentase terkecil setelah Papua Barat dalam hal kepadatan penduduk. Hal ini disebabkan karena semakin menyebarnya penduduk di suatu wilayah, maka menyebabkan fasilitas kesehatan pun sulit mengakses masyarakat di daerah tersebut. Hal itu menjadi salah satu faktor yang menyebabkan semakin banyaknya kasus HIV/AIDS yang ada di Papua sehingga menempati di posisi keempat dengan provinsi yang memiliki angka HIV/AIDS tertinggi di Indonesia. Sehingga mengakibatkan masyarakat di Papua sangat sulit untuk mendapatkan akses kesehatan terutama dalam pengobatan dan menangani HIV/AIDS, hal ini terjadi akibat di Papua masyarakatnya sangat tersebar.

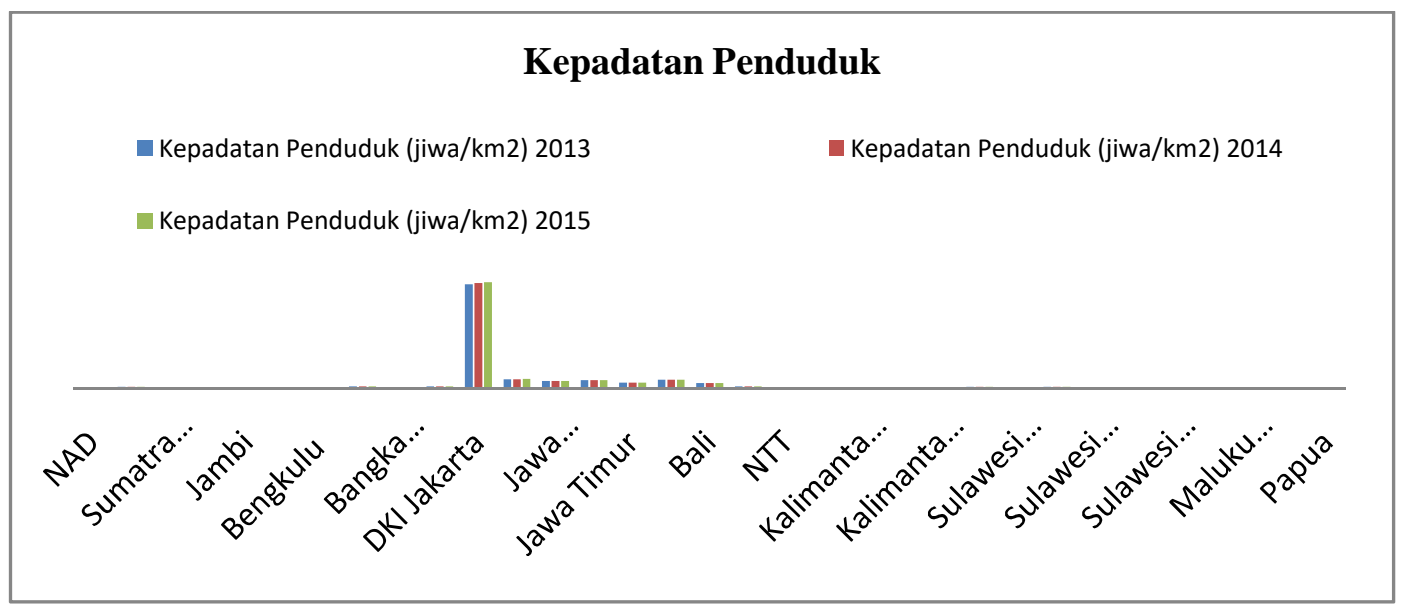

Sumber : BPS

Gambar 3. Jumlah Kepadatan Penduduk 2013-2015 di Indonesia

Variabel independen lainnya yang mempengaruhi tingkat HIV/AIDS yaitu indeks pembangunan manusia yang mempengaruhi jumlah kasus HIV/AIDS di Indonesia. Dimana jumlah p-value dari kepadatan sebesar 0,000 yang kurang dari 0,01 sehingga signifikan hingga level $1 \%$.

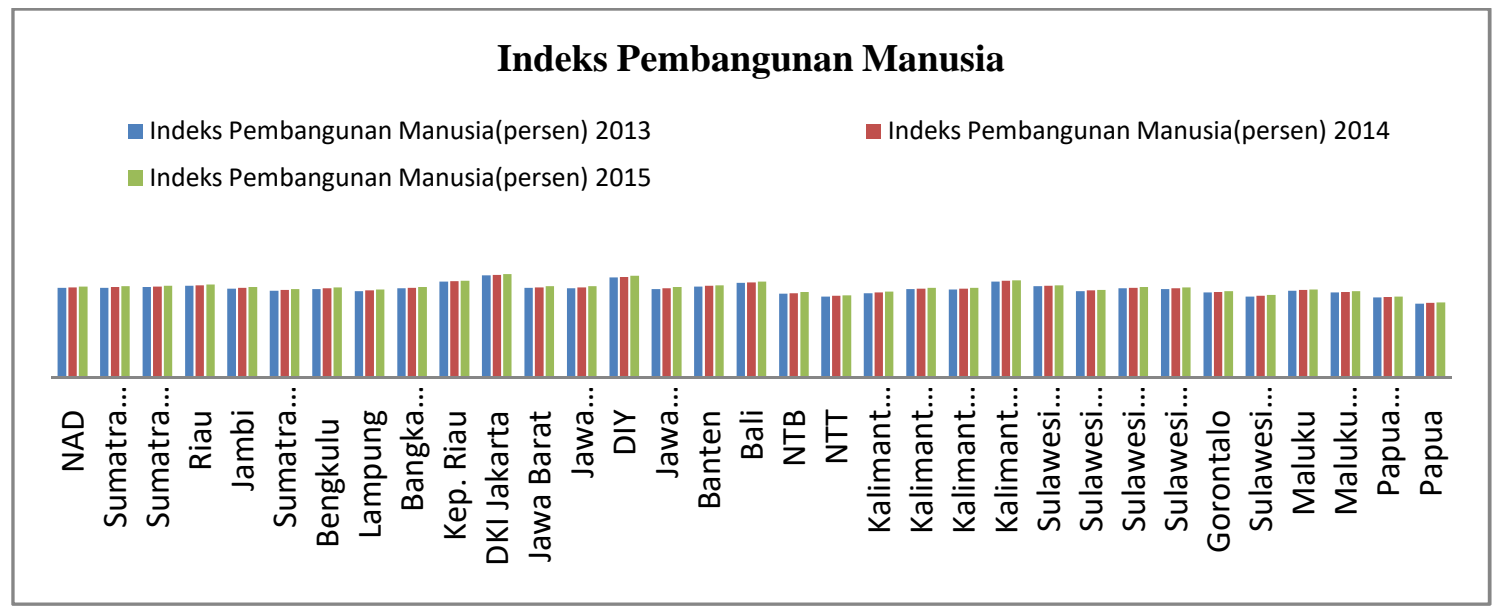

Sumber : BPS

Gambar 4. Indeks Pembangunan Manusia 2013-2015 di Indonesia 
Published July 2019

EKONOMIKAWAN : Jurnal Ilmu Ekonomi dan Studi Pembangunan

ISSN : $1693-7600$ (Print), ISSN : 2598-0157 (Online), http://jurnal.umsu.ac.Id/index.php/ekawan

"Indeks Pembangunan Manusia pertama kali ditemukan pada tahun 1990 oleh pemenang nobel India, Amartya Sen dan Mahbub Ul Haq. Sejak saat itu, digunakan oleh program pembangunan Perserikatan Bangsa-Bangsa (PBB) pada laporan tahunannya. Terdapat tiga indikator yang digunakan dalam mengukur Indeks Pembangunan Manusia (IPM) pada suatu negara, yaitu lama hidup yang diukur melalui angka harapan hidup,standar hidup yang diukur dengan pengeluaran perkapita yang disesuaikan menjadi paritas daya beli, dan pendidikan yang diukur berdasarkan rata-rata lama bersekolah dan angka melek huruf penduduk yang berada pada usia 15 tahun ke atas. Nilai IPM berkisar pada angka antara 0 hingga 100" (United Nations Development Programme, 2016).

Berdasarkan gambar 4, dapat dilihat bahwa provinsi Papua menjadi daerah yang memiliki IPM terendah. Berdasarkan data BPS, sejak 2010 hingga 2016, provinsi Papua berstatus IPM rendah, yaitu sebesar 58,05 poin. Hal itu disebabkan karena di provinsi Papua memiliki tingkat harapan hidup, pengetahuan, dan standar hidupyang bisa dibilang belum layak.Penduduk di provinsi Papua masih sulit untuk memperoleh pendapatan, kesehatan, dan pendidikan.

Saat ini, diperkirakan sebesar $20 \%$ penderita HIV/AIDS di Indonesia berada di provinsi Papua dan Papua Barat. Terlepas dari jumlah penduduk yang ada di kedua provinsi tersebut yang jauh lebih sedikit dibandingkan dengan jumlah penduduk di provinsi-provinsi lain di Indonesia.Dengan fasilitas kesehatan yang masih jarang dan sebaran penduduk yang luas, menjadikan tantangan bagi pelayanan kesehatan di kedua provinsi tersebut.Hal ini menjadikansalah satu faktor penyebab tingginya kasus HIV/AIDS di provinsi Papua dan Papua Barat.

Penulis juga melihat variabel independen lainnya yaitu rasio gini yang mempengaruhi jumlah kasus HIV/AIDS yang ada di Indonesia. Jumlah p-value dari kepadatan sebesar 0,007 yang kurang dari 0,01 sehingga signifikan hingga tingkat $1 \%$.

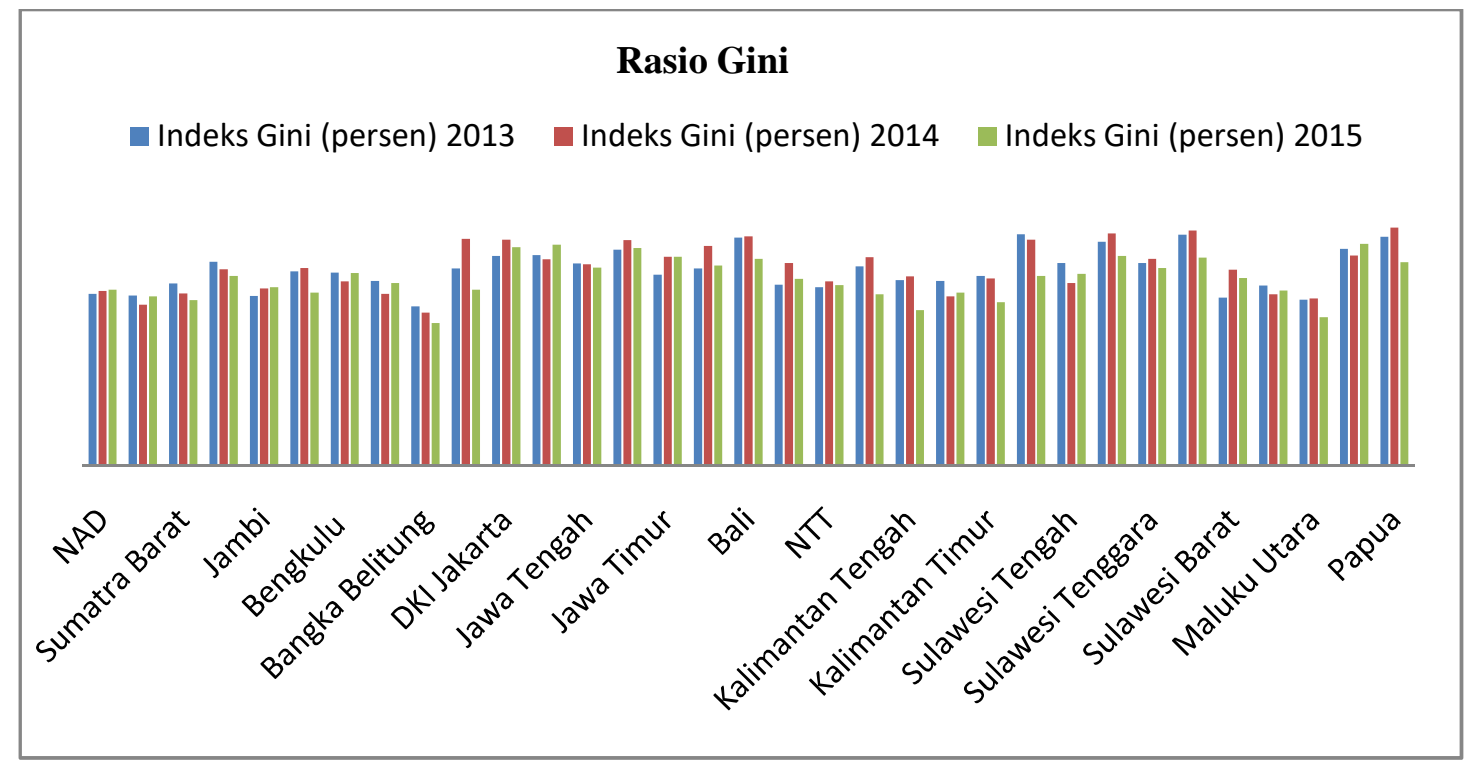

Sumber : BPS

Gambar 5. Rasio Gini 2013-2015 di Indonesia 
Published July 2019

EKONOMIKAWAN : Jurnal Ilmu Ekonomi dan Studi Pembangunan

ISSN : 1693-7600 (Print), ISSN : 2598-0157 (Online), http://jurnal.umsu.ac.Id/index.php/ekawan

Rasio gini merupakan salah satu alat yang dapat mengukur derajat ketidakmerataan distribusi pendapatan penduduk pada suatu negara.Angka rasio gini berkisar dari 0 hingga 1. Koefisien gini yang bernilai Omenunjukkan adanya pemerataan pendapatan yang sempurna pada suatu negara. Sebaliknya, rasio gini yang bernilai 1 mengindikasikan pemerataan pendapatan yang tidak sempurna atau terjadinya ketimpangan sempurna pada suatu negara.

Pada gambar 5 menunjukkan bahwa rasio gini tertinggi adalah provinsi Papua di tahun 2014. Hubungan antara rasio gini dan angka HIV/AIDS adalah positif, semakin tingginya rasio gini maka semakin tingginya kasus HIV/AIDS di suatu wilayah. Jadi, ketimpangan yang ada di masyarakat menjadi salah satu faktor yang dapat meningkatkan kasus HIV/AIDS di suatu wilayah. Papua sebagai provinsi yang memiliki rasio gini yang tinggi, hal ini berkorelasi positif dengan tingginya kasus HIV/AIDS di provinsi Papua sehingga menempati posisi keempat provinsi dengan angka HIV/AIDS tertinggi.

Masyarakat yang tinggal di lingkungan yang memiliki penghasilan rendah cenderung lebih rentan terhadap HIV/AIDS karena mereka tinggal di wilayah yang banyak orang dengan HIV/AIDS. Sehingga kemungkinan mereka terkena HIV/AIDS pun lebih besar, baik yang disebabkan seks bebas, penggunaan narkoba, atau beberapa penyebab lainnya. Ditambah lagi, apabila mereka berada di sebuah komunitas yang memungkinkan bertemu partner seks baru. Risiko ini jauh lebih tinggi ketimbang ketika orang tersebut lebih kaya dan tinggal di wilayah geografis yang lebih aman (Gardner et al., 2005).

Setelah penulis melakukan regresi dengan menggunakan Stata14, variabel independen yaitu persentase buta huruf, jumlah kepadatan penduduk (jiwa/ $/ \mathrm{km}^{2}$ ), indeks pembangunan manusia, dan rasio gini memiliki pengaruh yang signifikan terhadap jumlah kasus HIV/AIDS di Indonesia. Berikut hasil yang didapatkan dari regresi yang penulis telah lakukan menggunakan Stata14.

Tabel 1.Hasil Outreg

\begin{tabular}{|c|c|}
\hline VARIABLES & Fixed Effect \\
\hline Bthrf & $\begin{array}{c}176.1 * * * \\
(65.51)\end{array}$ \\
\hline Density & $\begin{array}{c}-4.168 * * * \\
(0.770)\end{array}$ \\
\hline Pop & $\begin{array}{l}-940.9 \\
(607.9)\end{array}$ \\
\hline IPM & $\begin{array}{c}242.1 * * * \\
(57.38)\end{array}$ \\
\hline Loggini & $\begin{array}{c}1,076 * * * \\
(387.9)\end{array}$ \\
\hline Constant & $\begin{array}{c}-8,793^{*} \\
(4,442)\end{array}$ \\
\hline Observations & 96 \\
\hline $\mathrm{R}$-squared & 0.408 \\
\hline Number of numwilayah & 32 \\
\hline
\end{tabular}


Published July 2019

EKONOMIKAWAN : Jurnal Ilmu Ekonomi dan Studi Pembangunan

ISSN : 1693-7600 (Print), ISSN : 2598-0157 (Online), http://jurnal.umsu.ac.Id/index.php/ekawan

Dari Tabel 1 dapat dilihat bahwa setiap variabel independen dapat mempengaruhi variabel dependen secara signifikan. Pada variabel rasio gini di log-kan menjadi variabel log gini dan untuk variabel lainnya tidak di log-kan atau tetap. Hasil regresi tersebut menghasilkan nilai $\mathrm{R}$-squared $\left(\mathrm{R}^{2}\right)$ sebesar 0,6008 yang menjelaskan bahwa setiap variabel independen dapat menjelaskan variabel dependen sebesar $60,08 \%$ dan sisanya sebesar $39,92 \%$ dijelaskan oleh variabel lain di luar model.

Kesadaran penderita HIV/AIDS di Indonesia untuk menjalankan pengobatan demi memperpanjang usianya dan selalu berperilaku positif atau tidak berniat untuk menularkan penyakitnya ke orang lain masih sangat rendah. Dengan memiliki sikap menghargai dan menghormati penderita HIV/AIDS melalui tidak melakukan diskriminasi, karena pada hakikatnya penderita HIV/AIDS tetap merupakan makhluk ciptaan Tuhan yang memiliki hak hidup, dengan cara tersebut diharapkan dapat menumbuhkan kesadaran para penderita HIV/AIDS untuk mengobati dirinya, tidak berniat menularkan penyakitnya ke orang lain, menambah semangat hidupnya, dan tetap berkarya.

Salah satu faktor bertambahnya jumlah pengidap HIV/AIDS di Indonesia adalah pencegahan penyebaran penyakit belum dilakukan secara komprehensif. Penanganan penyakit ini hanya ditangani oleh dinas kesehatan, sedangkan dinas-dinas lainnya belum terlibat secara maksimal. Seharusnya, tidak hanya dari pihak pemerintah, namun seharusnya seluruh lapisan masyarakat harus mengerti pengetahuan mengenai HIV/AIDS dan mengetahui bagaimana menanggulanginya dengan tujuan dapat mengurangi penyebaran virus HIV/AIDS di Indonesia. Selain itu, diharapkan jumlah tempat berobat serta konsultasi bagi penderita HIV/AIDS lebih diperbanyak lagi, baik oleh pemerintah maupun pihak swasta sehingga mampu mengurangi kasus HIV/AIDS di Indonesia.

\section{SIMPULAN}

Dilihat dari hasil penelitian dan pembahasan mengenai pengaruh pembangunan daerah yang meliputi persentase buta huruf, jumlah kepadatan penduduk (jiwa/ $/ \mathrm{km}^{2}$ ), indeks pembangunan manusia, dan rasio gini terhadap jumlah kasus HIV/AIDS di Indonesia sehingga mampu untuk menjelaskan mengenai hubungan antara variabel dependen dengan variabel independen. Penelitian dan pembahasan ini menggunakan data panel pada tahun 2013 hingga 2015.

Variabel-variabel independen mampu menggambarkan kondisi kasus HIV/AIDS di Indonesia sebesar 0,6008 atau sebesar 60,08\% dan sisanya sebesar 39,92\% digambarkan oleh variabel lain diluar model.

Kesimpulan akhir pada penelitian ini adalah variabel-variabel independen seperti persentase buta huruf, jumlah kepadatan penduduk (jiwa/ $/ \mathrm{km}^{2}$ ), indeks pembangunan manusia, dan rasio gini yang merupakan bagian dalam pembangunan daerah memiliki pengaruh signifikan terhadap jumlah kasus HIV/AIDS di Indonesia. 
Published July 2019

EKONOMIKAWAN : Jurnal Ilmu Ekonomi dan Studi Pembangunan

ISSN : 1693-7600 (Print), ISSN : 2598-0157 (Online), http://jurnal.umsu.ac.Id/index.php/ekawan

\section{DAFTAR PUSTAKA}

Badan Pusat Statistik.2017."Penduduk Buta Huruf menurut Kelompok Umur, 20112017".https://bps.go.id/linkTableDinamis/view/id/1056 (diakses pada 10 Mei 2018)

CDC. 1998. "Guidelines for the use of antiretroviral agents in pediatric HIV infection". MMWR, Vol. 47, No. 4: 1-43.

Hugo, Graeme. 2001. "Population Mobility and HIV/AIDS in Indonesia". Australia: UNDP South East Asia HIV And Development Office.

Indonesia, K. K. R. 2013. "Estimasi dan proyeksi HIV/AIDS di Indonesia tahun 20112016”. Kepala Studi Kesehatan Global di Fakultas Kesehatan Emory University, Dr. Carlos del Rio. (n.d.).

Kementerian Kesehatan Republik Indonesia. 2014. "Publikasi Data dan Informasi". http://www.depkes.go.id/resources/download/pusdatin/profil-kesehatanindonesia/profil-kesehatan-indonesia-2014.pdf (diakses pada 10 Mei 2018)

Kementerian Kesehatan RI. 2017. "Publikasi Data dan Informasi". http://www.kemkes.go.id/ (diakses pada 10 Mei 2018)

Kesehatan, K., \& RI, K. K. 2013. "Riset Kesehatan Dasar". Jakarta: Badan Penelitian dan Pengembangan Kesehatan Departemen Kesehatan Republik Indonesia.

Komisi Penanggulangan AIDS Nasional. 2017. "Komisi Penanggulangan AIDS". www.aidsindonesia.or.id/index.php?lang $=$ en (diakses pada 10 Mei 2018)

Kumar, Vinay, Cotran, et al. 2007. Buku Ajar Patologi Anatomi Edisi 7 Vol. 2. Jakarta: EGC pp 367.

Lewis, W. A. 1954. "Economic Development with Unlimited Supplies of Labour". The manchester school, Vol. 22, No. 2, 139-191.

Michael P. Todaro, S. 2002. "Pembangunan Ekonomi". Jakarta: Erlangga.

Population Action International. 2011. "Why Population Matters to Infectious Diseases and HIV/AIDS". Washington: Population Action International.

Riano, P. J. 2004. "The Current Situation of the HIV/AIDS Epidemic in Indonesia".

Rokhmah, D. 2013. "Implikasi Mobilitas Penduduk dan Gaya Hidup Seksual Terhadap Penularan HIV/AIDS".

UNESCO. 2017. "UNESCO's Response to HIV and AIDS". http://www.unesco.org/new/hiv-and-aids/ (diakses pada 10 Mei 2018)

World Health Organization. 2008. "The World Health Report 2008 - primary Health Care (Now More Than Ever)". https://www.who.int/whr/2008/en/ (diakses pada 10 Mei 2018)

Badan Pusat Statistik. (2007). Tingkat Kemiskinan di Indonesia Tahun 2007, (38), 1-5.

Data Kementrian Kes.Pdf. (n.d.).

Departemen Kesehatan. (2006). Situasi Hiv / Aids Di Indonesia Tahun 1987-2006, 3-4. https://doi.org/10.1007/s11908-003-0073-z

Gardner, L. I., Holmberg, S. D., Metsch, L. R., Anderson-Mahoney, P., Loughlin, A. M., del Rio, C., ... Access Study Study, G. (2005). Efficacy of a brief case management intervention to link recently diagnosed HIV-infected persons to care. Aids, 19(4), 423-431. Retrieved from http://pitt.summon.serialssolutions.com/link/0/eLvHCXMwY2BQSEs0MzEAFo5JBommxq mJBhZpiSapqeYp5uZJpsamiSYoKyqRSnM3UYYQN9cQZw9d6D0AugWmlsDsmAw6Qy XNMjktKdUk0SAtxTjV3MwUtCUSdJxciklSWrJZYlpaoqWBpYFJqklKmplZUrKpWZqB QVKyiUWiuaEYA28iaL14Xgl4W1kK34bt95N_q7t8mnpWm2-H_oTjAISzMto 
Published July 2019

EKONOMIKAWAN : Jurnal Ilmu Ekonomi dan Studi Pembangunan

ISSN : 1693-7600 (Print), ISSN : 2598-0157 (Online), http://jurnal.umsu.ac.id/index.php/ekawan

HHS, CDC, Ccid, NCHHSTP, \& Dhap. (2007). Cases of HIV infection and AIDS in the United States and Dependent Areas Percentages of persons aged 13 years and older living with HIV/AIDS and population, by race/ethnicity, 2007-34 states with confidential name-based HIV infection reporting Federal Rec. Centers for Disease Control and Prevention. HIV/AIDS Surveillance Report Centers for Disease Control and Prevention, 19(19), 63. Retrieved from http://www.cdc.gov/hiv/topics/surveillance/resources/reports/.\%0Ahttp://www.cdc.gov/hiv/t opics/surveillance/resources/reports/.

Nasional, S. S. E. (2017). Konsep dan definisi. Evaluation, 16.

No, F. S. (2017). Sulistya, 2016(45), 1-13.

Parker, D. C., Jacobsen, K. H., \& Komwa, M. K. (2009). A qualitative study of the impact of HIV/AIDS on agricultural households in southeastern Uganda. International Journal of Environmental Research and Public Health, 6(8), 2113-2138. https://doi.org/10.3390/ijerph6082113

Piot, P., Greener, R., \& Russell, S. (2007). Squaring the circle: AIDS, poverty, and human development. PLoS Medicine, 4(10), 1571-1575. https://doi.org/10.1371/journal.pmed.0040314

Purwaningsih, S. S., \& Widayatun, N. (2008). PERKEMBANGAN HIV DAN AIDS DI INDONESIA: Tinjauan Sosio Demografis. Jurnal Kependudukan Indonesia, 3(2), 75-95. https://doi.org/10.14203/JKI.V3I2.170

RI, K. (2002). Respon saat ini - Menangkal Ancaman Bencana Nasional AIDS mendatang. Penanggulangan HIV/AIDS Di Indonesia.

Rokhmah, D., Masyarakat, F. K., Jember, U., \& Timur, J. (2015). Sosial Transisi Untuk Pekerja Seks Komersial Dan Penutupan Prostitusi Terhadap Program Penanggulangan Hiv Aids Di, 03(02), 75-81.

United Nations. (2016). Human Development Report 2016. United Nations Development Programme. https://doi.org/eISBN: 978-92-1-060036-1

WHO. (2005). Immunological staging of HIV. Interim WHO Clinical Staging of HIV/AIDS and HIV/AIDS Case Definitions for Surveillance, 2, 8. https://doi.org/10.1016/S09688080(05)25177-7 